\title{
Can Increasing Cash Dividend Paid Improve Firm Value? Evidence from Chinese A-share Tourism Listed Firms
}

\author{
$\mathrm{HE} \mathrm{Xu}^{1 *, 2}$ \\ ${ }^{1}$ School of Business, Macau University of Science and Technology, Macau 999078, China \\ ${ }^{2}$ School of Finance \& Investment, Guangdong University of Finance, Guangzhou 510521, China \\ * Corresponding author e-mai: 694306315@qq.com
}

\begin{abstract}
Cash dividend distribution policy is an important part of listed firms' financing management, which affects the firm value. This paper takes the data of tourism firms in Chinese A-share market from 2015 to 2019 to empirically explore the impact of the cash dividend paid on the firm value. The study finds that increasing the cash dividend paid in the previous financial year can improve the firm value in the current financial year. Furthermore, Increasing the cash dividend paid in the previous financial year can improve the firm value of state owned tourism firms more than that of non-state owned tourism firms in the current financial year. The above conclusions not only help company executives to recognize effects of the cash dividend distribution policy in China and promote the financing management which encourages the healthy development of Chinese securities market, but also provide some enlightenment for the development of tourism firms.
\end{abstract}

Keywords: Cash dividend paid, Dividend distribution policy, Firm value, A-share tourism listed firms

\section{INTRODUCTION}

With a rapid development of the securities market in China, companies have gained more channels in financing, and individual investors also have more choices in their asset investment. The cash dividend paid is not only related to companies' financing and development, but also related to individual investors' preference for choosing stocks. Therefore, whether from the perspective of listed firms or investors, the cash dividend paid is a hot topic of the widespread concern. Cash dividend paid is a kind of dividend distributions in which listed firms draw part of profits to return to the investors in cash according to their shares after keeping retained earnings from profits. The cash dividend distribution depends on the internal management judgment and external regulatory policies. Generally speaking, when firms have good investment opportunities, the management tend to keep more capitals for the investment and reduce the cash dividend distribution level. On the contrary, when investment opportunities are not so much worthy, their management tend to pay cash dividends to shareholders and reduce the investment level. From the perspective of the external supervision, China Securities Regulatory Commission and other relevant regulatory departments have been committed to guide the promotion mechanism of the cash dividend distribution in listed firms, so as to change "Iron Rooster" phenomenon in A-share market and protect rights and interests of individual investors. Now more than $75 \%$ of listed firms implement cash dividend distribution every year from 2017 to 2019 , and the scale of dividends increases year by year. Recently, the average annual cash dividend rate is maintained at more than $35 \%$.

In the long run, the cash dividend paid determines the investment behavior of investors and affects the level and trend of the firm value in the securities market. There has been a controversy for the relation of the cash dividend paid and the firm value in academic fields. Some researchers believe that the low cash dividend paid and the high retained earnings can not only reduce the financial pressure of companies but also help to reinvest, which improves the firm value [9]. However, other researchers believe that the high cash dividend paid can improve the firm value, as a way to gain a good reputation that reduces firms financing costs in the future [6] [7]. To explore the relation of the cash dividend paid and the firm value, this paper makes an empirical study from the 2015- 
2019 data of A-share tourism listed firms, and find that increasing of the cash dividend paid improves the firm value, and further analyzes the different impacts of the cash dividend paid on the firm value in the firm heterogeneity.

The main contributions of this paper are as follows: First, most of existing studies take all A-share listed firms as samples to conduct the overall research, and pay less attention to samples for tourism firms for the impact of the cash dividend paid on the firm value, so we enrich research results of the corporate finance in the tourism field. Second, the cash dividend paid issue has always been a hot topic of the corporate governance, and this paper provides an empirical reference for the research of the corporate micro-governance. Third, this paper provides a practical value for understanding the current situation of cash dividend distribution policies in China, improving the financial management of listed firms and the ability of the supervision department to guide the cash dividend distribution which improves the completion of the securities market.

\section{BASIC THEORIES}

In order to improve the firm value, listed firms carry out the financial management, which includes dividend paid policies as the the most common implements. When companies decide to pay dividends to shareholders, the dividend paid rate and the retained earnings level are factors considered by the management to formulate a dividend distribution policy. Considering the complexity of financial structures and development plans in companies, as well as internal and external factors of their dividend distribution policies, there are two different views on the relation of the dividend paid and the firm value: Irrelevant dividend view and relevant dividend view.

In 1961, American scholars Miller and Modigliani put forward the "Irrelevant Dividend View" (MM theory). On the premise of several assumptions, including that information can be easily obtained sufficiently, which means there is no transaction cost and expense, the competitive market is completely perfect without tax and all the debt is risk-free. In this situation, the stock price and the firm value of listed firms do not fluctuate with the change of dividend distribution policies [1]. However, in reality, this theory is too idealistic and lack of dynamic analysis, so it is difficult to apply to the actual market. But this theory provides a specific direction to later researchers and greatly promotes the extension and exploration of the relation of the dividend paid and the stock price fluctuation with the firm value.

Proponents of "Relevant Dividend View" believe that conditions of MM theory are too harsh to apply in the imperfect competitive market. Main views for the relation of the dividend paid and the firm value are focused on the "Bird-in-Hand" theory, the signaling theory, the agency theory, the tax difference theory and the clientele effect theory:

A. "Bird-in-Hand" theory: Through the analysis of the dividend discount model, the conclusion is that companies are more willing to reinvest their retained earnings which promote the firm value more in capitals comparing with dividend paid distributions do [2]. However, shareholders prefer to obtain relatively lower cash dividends at present and not to take risks to choose higher uncertain capital gains from the reinvestment in the future. The reason is that higher capital gains from the reinvestment in the future are too uncertain to expect at sometimes, and the reinvestment risk will be further expanded as time goes by. If the reinvestment fails, the dividends will be less or even disappear to shareholders. Therefore, the stock price that reflects the firm value according to investors' expectation is directly proportional to the dividend paid.

B. Agency theory: Jensen and Mecking pointed out in 1976 that although investors as principals aim to maximize shareholders' interests, top managers as agents is more likely to maximize their own interests; so the agency cost is caused by the confliction of interests between principals and agents [3]. Positive dividend distribution policy can not only urge top managers to improve management performance, but also reduce retained earnings and the free cash flow, guiding managements to looking for new investment opportunities for new capitals, which promotes the investment efficiency for their firm value improvement.

C. Signaling theory: In reality, there is no completely informative circulation and the transmission of information is asymmetric among investors, management and creditors. Top managers hold the most specific true financial and developmental information of the company, but they may spread the whitewashed information of the company financing, causing investors to make improper investment decisions. Then Lintner put forward "Dividend smoothing theory" in 1956, that is, managements should consider to transmit the sincere and responsible signals to the market when formulating dividend distribution policies, because maintaining a long-term stable dividend rate can help a stable development of the firm value [4].

D. Tax difference theory: Farrar and Selwyn believe that investors should consider the tax difference between capital gains and cash dividends when they choose to sell stocks for capital gains or continue to hold stocks for cash dividends. And the tax rate of capital gains in most countries is lower than that of cash dividends [5]. Therefore, investors are more willing to obtain capital gains. According to the tax difference theory, dividend distribution policies affect the firm value. It means the low rate of dividend distribution policies and the 
intertemporal dividend payment are ways to maximize the firm value.

E. Clientele effect theory: This theory points out that investors' preferences for dividend distribution policies are determined by their own tax burden level [1]. High income investors with high tax rate prefer the low rate of dividend distribution policies, who hope to continue to hold rising price stocks to obtain more capital gains; low income investors with low tax rate prefer the high rate of dividend distribution policies, who hope to obtain stable and higher cash dividends. Companies adjust dividend distribution policies timely, to attract strategic investors with low dividends and small investors with high dividends. In fact, the clientele effect theory is the extension and development of the tax difference theory, which explores investors' different attitudes with different income who choose unlike dividend distribution policies because of their own marginal tax rate level.

According to the above theories, the dividend paid (including the cash dividend paid) affects the firm value in reality. Under the goal of maximizing firm value, companies choose their optimal dividend distribution plans.

\section{LITERATURE REVIEW RESEARCH HYPOTHESIS}

AND

According to above basic theories, dividend distribution policies and the cash dividend paid level have an impact on the firm value. Scholars study the relation of cash dividend distribution policies and the firm value on the basis of the agency theory and the signaling theory, and draw different conclusions. Generally speaking, a certain amount of the cash dividend paid can prove companies profitability and convey the optimistic growth information simultaneously, so as to attract more investors to buy stocks, which benefits the firm value. On the contrary, lower cash dividend paid are not optimistic for investors, so as to sell stocks, which harms the firm value. Some scholars believe that the cash dividend paid of firms with higher firm value is often at the higher rate [6]. Firms should formulate a stable dividend distribution policy and increase the cash dividend paid to improve the firm value. The cash dividend distribution can effectively reduce the agency cost of shareholders and improve the firm value in certain condition with loose market constraints [7]. And there is an empirical analysis which concludes that the cash dividend has a significantly positive correlation with the firm value in Chinese Ashare market [8]. However, some scholars find that the cash dividend paid is negatively correlated with the firm value [9]. Some scholars even believe that the cash dividend paid has an inverted "U" relation with the firm value, and firms may be short of capitals for the investment due to the excessive cash dividend distribution policy [10]. These firms must solve the capital shortage by outside financing, and new coming creditors can reduce the agency cost by supervising managements.

To sum up, this paper puts forward the following assumptions:

H1a: Increasing the cash dividend paid of the previous financial year can improve the firm value of the current financial year.

H1b: Increasing the cash dividend paid of the previous financial year can suppress the firm value of the current financial year.

\section{RESEARCH DESIGN}

\section{1) Sample Selection and Data Sources}

This paper selects A-share tourism listed firms samples from 2015-2019. In order to make the data more in line with the reality and improve the authenticity of the conclusion, this paper eliminates abnormal companies data such as ST companies data. ST companies are poor in management and suffer losses more than three years, and their cash dividend paid are limited, which easily leads to the inconsistency between empirical results and the actual situation. And companies with negative net profit are excluded. Because the operating profit is the basis of dividend distribution policies of firms. The continuous variables are winsorized with $1 \%$ and 209 samples are obtained. We get the data from CSMAR database and manually calculate and supplement the missing data by annual reports.

\section{2) Research Model and Variable Design}

Through the research design of other scholars [6], this paper establishes the following regression model:

$$
\begin{aligned}
& \text { Tobi nQ }=\alpha+\beta_{1}{ }^{*} \operatorname{Dcash}_{i, t-1}+\beta_{2}{ }^{*} \mathrm{RCE}_{1, t-1}+\beta_{3}{ }^{*} \mathrm{LEV}_{i, t-1}+\beta_{4}{ }^{*} \mathrm{TAT}_{i, t-1} \\
& +\beta_{5}{ }^{*} \operatorname{SCR}_{, t-1}+\beta_{6}{ }^{*} \mathrm{SI} \mathbb{E}_{1, t-1}+\sum \text { Ind }+\sum \text { YEAR }+\varepsilon_{i, t}
\end{aligned}
$$

In the model (1), $\alpha$ is the intercept term, $\beta_{\mathrm{i}}$ is the estimation coefficient corresponding to each variable, and $\varepsilon$ is the random disturbance term.
A. Explained Variable: The explained variable is the firm value, expressed as TobinQ, which not only reflects the future value of firms but also has the theoretical and practical operability. So considering the actual situation 
of listed firms in China, this paper uses TobinQ and the formula is:

TobinQ $=($ Circulating Shares $*$ Closing Price + Non Circulating Shares * Net Assets per Share + Book Value of Liabilities)/Book Value of Total Assets

B. Explanatory Variable: The explanatory variable is the cash dividend paid, expressed as Dcash, which represents the cash dividend paid per share.
C. Control Variables: Return on Net Assets (ROE) is used to measure the profitability; Asset-liability Ratio (LEV) is used to measure the solvency; Total Assets Turnover (TAT) is used to measure the operational capability; Sales Growth Rate (SGR) is used to measure the growth capability and the firm size (SIZE) is used to measure the scale. In the empirical analysis, we add industry and year dummy variables (Ind and YEAR) to control the fixed effect. The specific definition and measurement of variables are shown in Table 1.

Table 1. Variables Definition

\begin{tabular}{c|c|c|c}
\hline $\begin{array}{c}\text { Type of } \\
\text { Variable }\end{array}$ & Name of Variable & Variable Meaning & Computing Method \\
\hline $\begin{array}{c}\text { Explained } \\
\text { Variable }\end{array}$ & TobinQ & Firm Value & $\begin{array}{c}\text { (Circulating Shares * Closing Price + Non Circulating } \\
\text { Shares * Net Assets per Share + Book Value of } \\
\text { Liabilities)/Book Value of Total Assets }\end{array}$ \\
\hline $\begin{array}{c}\text { Explanatory } \\
\text { Variable }\end{array}$ & Dcash & Cash Dividend Paid & Cash Dividend/Earnings per Share \\
\hline $\begin{array}{c}\text { Controlled } \\
\text { Variables }\end{array}$ & $\begin{array}{c}\text { ROE } \\
\text { LEV }\end{array}$ & $\begin{array}{c}\text { Return on Net Assets } \\
\text { Asset-liability Ratio } \\
\text { Total Assets Turnover }\end{array}$ & $\begin{array}{c}\text { Net Profit/Net Assets } \\
\text { Total Liabilities/Total Assets } \\
\text { Total Revenue/Total Assets }\end{array}$ \\
& SGR & Sales Growth Rate \\
SIZE & Firm Size & Growth Income in Current Period/Income in Previous \\
Period
\end{tabular}

\section{EMPIRICAL ANALYSIS}

1) Descriptive Statistics

The descriptive statistics of the whole sample are shown in Table 2. The maximum value of TobinQ is 12.400 and the minimum value is 0.885 , which to some extent reflects the management level and strategic differences of tourism companies. The average value of Dcash is 0.300 and the standard deviation is 0.077 , which indicates that the cash out level of the tourism is not active completely by government incentive policies for the cash dividend paid. For control variables, the average value of ROE is 0.083 , which means that as long as the ROE is greater than 0.083 , it can be considered that the company performance is better than half of the company samples'. The average value of LEV is 0.394 , which reflects that the overall debt level of the tourism is moderate. The average value of SGR is 0.187 , the maximum value is 1.877 , and the minimum value is 0.423 , which can be seen that the overall growth ability of the tourism is not optimistic and there are great differences between these companies.

Table 2. Descriptive Statistics

\begin{tabular}{lllllll}
\hline \multicolumn{1}{c}{ Variables } & Obs & \multicolumn{1}{c}{ Mean } & Median & Max & Min & Std.Dev \\
\hline TobinQ & 209 & 2.975 & 2.300 & 12.400 & 0.885 & 4.560 \\
Dcash & 209 & 0.300 & 0.262 & 1.615 & 0.005 & 0.077 \\
ROE & 209 & 0.096 & 0.083 & 0.360 & 0.004 & 0.005 \\
LEV & 209 & 0.394 & 0.380 & 0.847 & 0.058 & 0.037 \\
TAT & 209 & 0.648 & 0.556 & 2.494 & 0.091 & 0.174 \\
SGR & 209 & 0.187 & 0.126 & 1.877 & -0.423 & 0.110 \\
SIZE & 209 & 22.102 & 21.967 & 25.715 & 19.981 & 1.422 \\
\hline
\end{tabular}

\section{2) Correlation Analysis}

Table 3 shows that when the cash dividend paid of tourism listed firms is higher, the firm value is higher, which is a significant correlation at 5\% level. This result preliminarily verifies H1a. 
Table 3. Pearson Correlation Coefficients

\begin{tabular}{|c|c|c|c|c|c|c|c|}
\hline & TobinQ & Dcash & ROE & LEV & TAT & SGR & SIZE \\
\hline TobinQ & 1 & & & & & & \\
\hline Dcash & $0.0642^{* *}$ & 1 & & & & & \\
\hline ROE & $0.318^{* * *}$ & $0.0876^{* *}$ & 1 & & & & \\
\hline LEV & $-0.4771^{* \star *}$ & $-0.1977^{\star \star \star}$ & $-0.0889^{\star^{* *}}$ & 1 & & & \\
\hline TAT & $0.0144^{*}$ & 0.0454 & $0.2855^{\star \star \star}$ & 0.0174 & 1 & & \\
\hline SGR & $0.0743^{\star * \star}$ & $-0.0836^{\star \star \star}$ & $0.2501^{* *}$ & $0.0538^{*}$ & $0.1606^{\star *}$ & 1 & \\
\hline SIZE & $-0.6242^{\star * *}$ & -0.0281 & 0.0041 & $0.5784^{\star \star \star}$ & $-0.0611^{\star \star}$ & -0.0034 & 1 \\
\hline
\end{tabular}

Note: Significance at the $1 \%, 5 \%$, and $10 \%$ levels is indicated by $* * *, * *$, and $*$, respectively.

Table 4 shows that variance expansion factors of variables are less than 5 , which means that there is no multicollinearity among these variables. We can use these variables for the regression analysis below.

Table 4. Vif Test Analysis

\begin{tabular}{ccc}
\hline Variables & VIF & 1/VIF \\
\hline Dcash & 1.070 & 0.936 \\
ROE & 1.030 & 0.968 \\
LEV & 1.590 & 0.629 \\
TAT & 1.040 & 0.962 \\
SGR & 1.010 & 0.988 \\
SIZE & 1.530 & 0.655 \\
\hline Mean VIF & 1.210 &
\end{tabular}
Value

3) Regression Analysis of Cash Dividend paid to Firm

Table 5 shows regression results of the cash dividend paid $\left(\right.$ Dcash $\left._{i, t-1}\right)$ to the firm value $\left(\right.$ TobinQ $\left.{ }_{i, t}\right)$. Without controlling Ind and YEAR effect, the coefficient of Dcash $_{\mathrm{i}, \mathrm{t}-1}$ in the first regression column is 0.207 , which is significant at 5\% level. After controlling Ind and YEAR effect, the coefficient of Dcash ${ }_{i, t-1}$ in the second regression column is 0.119 , which is significant at $5 \%$ level. The results of two columns show that the higher the cash dividend paid of the previous year, the larger the firm value of the current year, which verifies the H1a of this paper. It means that increasing the cash dividend paid can improve the firm value.
Table 5. Regression Results of Cash Dividend Paid to Firm Value

\begin{tabular}{|c|c|c|}
\hline Variables & TobinQ ${ }_{i, t}$ & Tobin $Q_{i, t}$ \\
\hline \multirow[t]{2}{*}{ Dcash $_{\mathrm{i}, \mathrm{t}-1}$} & $0.207^{* *}$ & $0.119^{* *}$ \\
\hline & $(3.050)$ & (2.297) \\
\hline \multirow[t]{2}{*}{$\mathrm{ROE}_{\mathrm{i}, \mathrm{t}-1}$} & $8.23^{\star \star \star \prime}$ & $5.060^{\star \star \star}$ \\
\hline & (36.104) & $(25.253)$ \\
\hline LEV $_{\mathrm{i}, \mathrm{t}-1}$ & $\begin{array}{l}-0.769^{* * *} \\
(-10.007)\end{array}$ & $\begin{array}{l}-0.512^{* * *} \\
(-6.671)\end{array}$ \\
\hline TAT $_{i, t-1}$ & $\begin{array}{l}-0.410^{* *} \\
(-20.972)\end{array}$ & $\begin{array}{l}-0.210^{* \star} \\
(-5.255)\end{array}$ \\
\hline$S G R_{i, t-1}$ & $\begin{array}{c}1.409^{* *} \\
(14.510)\end{array}$ & $\begin{array}{l}0.298^{* * x} \\
(5.698)\end{array}$ \\
\hline $\operatorname{Size}_{\mathrm{i}, \mathrm{t}-1}$ & $\begin{array}{l}-0.714^{* * *} \\
(-51003)\end{array}$ & $\begin{array}{l}-0.633^{\text {*** }} \\
(-48142)\end{array}$ \\
\hline Constant & $\begin{array}{c}18.29^{* * *} \\
(60.573)\end{array}$ & $\begin{array}{c}16.72^{* \star \star} \\
(56.831)\end{array}$ \\
\hline Year & No & Yes \\
\hline Ind & No & Yes \\
\hline Observations & 209 & 209 \\
\hline Adjusted $\mathrm{R}^{2}$ & 0.477 & 0.475 \\
\hline
\end{tabular}

Note: The t-statistics reported in parentheses. Significance at the $1 \%$, $5 \%$, and $10 \%$ levels is indicated by ${ }^{* * *},{ }^{* *}$, and ${ }^{*}$, respectively.

The coefficient of $\mathrm{ROE}_{\mathrm{i}, \mathrm{t}-1}$ is significantly positive, indicating that the increase of the return on equity can improve the firm value. The coefficient of $L_{E V} V_{i, t-1}$ is significantly negative, indicating that the higher the assetliability ratio is, the lower the solvency is, which decreases the firm value. The coefficient of $\mathrm{TAT}_{\mathrm{i}, \mathrm{t}-1}$ is significantly negative, which indicates that the increase of the total asset turnover does not necessarily improve the firm value. The coefficient of $\mathrm{SGR}_{\mathrm{i}, \mathrm{t}-1}$ is significantly positive, indicating the increase of the sales growth rate can raise the firm value. The coefficient of SIZE $_{i, t-1}$ is significantly negative, which means that the expansion of the firm size does not necessarily promote the growth of the firm value. The above results are basically in line with our expectations.

4) Regression Analysis of Cash Dividend paid to Firm Value in Different Groups of Firm Heterogeneity 
Firm heterogeneity refers to characteristic differences in the ownership, the organization mode, the scale, the human capital, the establishment year and the property right of firms, which is manifested as the productivity differences in companies. The heterogeneity of property rights between state-owned firms and non-state owned firms leads to the difference of the debt and capital structure, which makes to the significant difference in the level of the cash dividend distribution. State owned firms mean that their equity is owned by the state, whose financing are easier to get help of the government, banks and other financial institutions, with less constraints; while non-state owned firms' financing are often limited by the reputation and external government policies, with more constraints. Moreover, these different holding types of listed firms lead to differences in the preferences and proportion of the cash dividend distribution. Therefore, according to the heterogeneity of property rights of tourism firms, this paper makes the regression analysis of the cash dividend paid to the firm value in two different groups (SOE group and N_SOE group).

Table 6 shows the impact of the cash divide paid $\left(\right.$ Dcash $\left._{\mathrm{i}, \mathrm{t}-1}\right)$ on the firm value (TobinQ $\left.\mathrm{Q}_{\mathrm{i}, \mathrm{t}}\right)$ in SOE group and N_SOE group. Dcash ${ }_{\mathrm{i}, \mathrm{t}-1}$ of state-owned firms is 0.146 and that of non-state owned firms is 0.096 , which are significant at $5 \%$ and $10 \%$ respectively. This result indicates that comparing with non-state owned firms, state owned firms which improve the cash dividend paid in the previous financial year can better improve the firm value of the current financial year.

Table 6. Regression Results of Cash Dividend Paid to Firm Value in Firm Heterogeneity

\begin{tabular}{|c|c|c|}
\hline Variables & $\begin{array}{c}\text { SOE } \\
\text { TobinQ }\end{array}$ & $\begin{array}{l}\text { N_SOE } \\
\text { TobinQ }\end{array}$ \\
\hline \multirow[t]{2}{*}{ Dcash $_{i, t-1}$} & $0.146^{* *}$ & $0.096^{*}$ \\
\hline & $(2.205)$ & (1.912) \\
\hline \multirow[t]{2}{*}{$\mathrm{ROE}_{\mathrm{i}, \mathrm{t}-1}$} & $3.474^{4 * *}$ & $5.681^{* *+x}$ \\
\hline & $(4.166)$ & (6.625) \\
\hline \multirow[t]{2}{*}{$\operatorname{LEV}_{\mathrm{i}, \mathrm{t}-1}$} & $-0.578^{*}$ & $-0.443^{* *}$ \\
\hline & $(-1.800)$ & $(-2.224)$ \\
\hline \multirow[t]{2}{*}{$\mathrm{TAT}_{\mathrm{i}, \mathrm{t}-1}$} & $-0.201^{\text {t*t*}}$ & $-0.120^{* *}$ \\
\hline & $(-5.224)$ & $(-1.949)$ \\
\hline \multirow[t]{2}{*}{$S G R_{i,-1}$} & $0.431^{4 * *}$ & $0.150^{* *}$ \\
\hline & $(3.678)$ & (1.805) \\
\hline \multirow[t]{2}{*}{ Size $_{i, t-1}$} & $-0.544^{* * *+}$ & $-0.641^{*+*}$ \\
\hline & $(-3.782)$ & $(-4.959)$ \\
\hline \multirow[t]{2}{*}{ Constant } & $14.56^{* * * *}$ & $16.73^{x+t}$ \\
\hline & $(4.512)$ & $(5.877)$ \\
\hline Year & Yes & Yes \\
\hline Ind & Yes & Yes \\
\hline $\mathrm{F}$ & $7.560^{* * * *}$ & $5.530^{* *+*}$ \\
\hline Adjusted R2 & 0.372 & 0.324 \\
\hline
\end{tabular}

Note: The t-statistics reported in parentheses. Significance at the $1 \%, 5 \%$, and $10 \%$ levels is indicated by ${ }^{* * *},{ }^{* *}$, and ${ }^{*}$, respectively.

\section{CONCLUSION AND SUGGESTION}

Based on samples of tourism listed firms in China from 2015-2019, this paper examines the relation of the cash dividend paid and the firm value, and their performance in different groups of the firm heterogeneity. The results show that: First, increasing the cash dividend paid of the previous financial year can improve the firm value of the current financial year, which means that the cash dividend paid has a lagging impact on the firm value. Second, comparing with non-state owned firms, state owned firms which improve the cash dividend paid in the previous financial year can better improve the firm value of the current financial year.

Cash dividend paid can transmit a large of firm information to the market. Firms with good management and abundant capitals should be encouraged to increase their cash dividends, which is helpful to increase the certainty of shareholders' return and forms a "return to reinvestment" market circulation. Capable tourism listed firms should fully consider improving their cash dividend paid and transmit the signal of good development to the market, which is conducive to increase their firm value. State owned tourism listed firms should use their own financing advantages to improve cash dividend distribution policies in the secondary market, so as to attract more investors and give fully play to the role in promoting their firm value. Government should further improve the supervision mechanism of cash dividend distribution policies, strengthen the information disclosure intensity of the cash dividend distribution, enhance the transparency of financial information and non-financial information, and ensure the governance effect of relevant policies in Chinese A-share market.

\section{REFERENCES}

[1] Miller M.H., Modigliani F. (1961) Dividend policy, growth, and the valuation of shares. J. The Journal of Business, 34: 411-433.

[2] Gordon M.J. (1963) Optimal investment and financing policy. J. The Journal of finance, 18: 264 272.

[3] Jensen M.C., Meckling W.H. (1976) Theory of the firm: Managerial behavior, agency costs and ownership structure. J. Journal of financial economics, 3: 305-360.

[4] Lintner J. (1956) Distribution of incomes of corporations among dividends, retained earnings, and taxes. J. The American economic review, 46: $97-$ 113.

[5] Farrar D.E., Selwyn L.L. (1967) Taxes, corporate financial policy and return to investors. J. National Tax Journal, 20: 444-454. 
[6] Gong G.M., Long L. (2009) Dividend Level, Dividend Stability and Enterprise Value. J. Communication of Finance and Accounting, 27: 35 .

[7] Yu L., Liang T.Y. (2013) Governance effect of the dividend policy: Based on financing constraints and agency cost trade-offs. J. Soft Science, 27: 67-70.

[8] Zhang Z.S. (2010) An empirical study on the relationship between enterprise value and dividend policy. J. New accounting, 5:12-15

[9] Yang H.M. (2008) Empirical Research on the Relationship between Cash Dividend and Enterprise's Value. J. Statistical Research, 8: 65-68.

[10] He J. (2009) An empirical study on the relationship between cash dividend policy and enterprise value in China -- from the perspective of agency theory. D. Southwestern University of Finance and Economics 